\title{
Posthumous Reputation Unravelled in Sixteenth-Century Epitaph Fictions
}

\author{
Helen Swift \\ St Hilda’s College, Oxford
}

Abstract

Epitaphs record a person's death, a life that was. Literary epitaphs of the later fifteenth and early sixteenth centuries provided an opportunity, through the medium of verse and prose fiction, for anticipating death and projecting into the future the afterlife that will be constituted by a person's posthumous reputation. This paper re-assesses writers’ goals in contriving an epitaph fiction $\div$ Ffar from aiming at monumentally immobilising reputation as an immutable product of their writing, as most critics have argued, they manifest a keener interest in unpicking the processes by which someone's identity is transmitted; they-and in-exposeing the precariousness and malleability of what is being communicated to posterity. I unpack epitaphic processes of identity construction and their precarities by focusing especially on the plurality of identity narratives that results from competing agencies shaping a person's afterlife. I then pick up on their questioning of the nature of reputation as an afterlife, how the mode of posthumous being that is envisaged is (or is not) defined in terms of life and death. The paper concludes with a reflection on how late-medieval epitaph fictions may usefully inflect critical thinking on afterlives.

Keywords

André de La Vigne, Death, Deixis, Epitaph, Jean Bouchet, Jean Lemaire de Belges, Reputation

I have been through and shortened sentences where appropriate (and made a few other adjustments to phrasing to abbreviate/clarify). I've inserted a 'see above' for the reference that was said to be missing to Garnier (the quote had been referenced earlier in the article ; I've promoted the attribution from the footnote to the main text, for clarity) 
This volume is preoccupied by an essential futurity in posterity, a concern with the 'downstream context' of a human life. ${ }^{1}$ Epitaphs constitute an interesting point of temporal and ontological articulation between life and death, insofar as they look backwards - recording a person's death, a life that was - in order to project a record of that life forwards into the memory of those passers-by who will view its text and recall the deceased in that anticipated instant. Epitaphic discourse is fundamentally 'temporally situated in that future moment of reading' which is its 'deictic centre' ${ }^{2}$. Iits pre-authored cy gist is located in the here and now of its destined audience, who are not presented with someone's afterlife as a product, a ready-made given, but instead themselves construct that afterlife through a compositional process of engagement with past, present and future. Such theorization of how an epitaph works may be demonstrated in practice through the literary example of André de La Vigne’s Complaintes et Epitaphes du roy de la Bazoche (1501). De La Vigne’s poem is a dream-vision narrative framing a set of laments and epitaphs in memory of Pierre de Baugé, who, recently deceased, had held the title of 'the king of the Basoche', the head of the guild of legal clerks of the Palais de Justice. ${ }^{3}$ Personified representatives of the guilds of four cities are seen, the persona tells us, bringing forward 'les epitaphes que cy après s’ensuyvent' (l. 462). ${ }^{4}$ Each eleven-line verse epitaph offers tribute to the deceased and presents itself deictically as being inscribed into his tomb:

Sous ceste amère, dure et dolente pierre

Gist nostre Roy basilical, dit Pierre. ${ }^{5}$

An epitaph offered by the Basoche of Bordeaux (each personification provides two) evokes provocatively the role of the reader:

Pour les passans du long cest ambulacre

Est et sera pourtraict le simulacre

Du noble Roy, que Mort nous veult oster

Vif en vertus, plus hault volant qu'un sacré. ${ }^{6}$

${ }^{1}$ On the coinage and use of the downstream metaphor, see Terence Cave, 'Epilogue: Time's Arrow', in PreHistories and Afterlives: Studies in Critical Method, ed. by Anna Holland and Richard Scholar (London Legenda, 2009), pp. 135-46 (p. 141); Cave, Mignon's Afterlives: Crossing Cultures from Goethe to the TwentyFirst Century (Oxford: OUP, 2011), p. 37; Holland and Scholar, 'Introduction', in Pre-Histories, pp. 1-13 (p.

${ }^{2}$ Neil Kenny, Death and Tenses: Posthumous Presence in Early Modern France (Oxford: OUP, 2015), p. 117. ${ }^{3}$ Recueil de poésies françoises des $X V^{e}$ et $X V I^{e}$ siècles: morales, facétieuses, historiques, I-XIII (1855-78), ed. by Anatole de Montaiglon and James de Rothschild, XIII (Paris: Daffis, 1878), pp. 383-413.

${ }^{4}$ For the relationship between 'epitaphe' and 'complainte', see Helen J. Swift, Representing the Dead: Epitaph Fictions in Late Medieval France (Cambridge: Brewer, 2016), pp. 11-13.

${ }^{5}$ Complaintes et Epitaphes du roy de la Bazoche (henceforth CERB), ll. 463-44: the Basoche of Toulouse.

${ }^{6}$ CERB, 1l. 474-77. 
The 'passans' designate, on one level, physical passers-by. They-whe activate the text of an epitaph through theirby reading efit in their own present, projected as both present and future ('est et sera'), and whe can see, in a funerary monument setting, the effigy ('simulacre') of the deceased adorning the tomb into which the epitaph is engraved. On another level, the 'passans' also represent readers passing through the text of the poem. They whoput together imaginatively the identity of the departed through theirby reading of the sequence of eight epitaphs as a collectivity. This is a highly active interpretative process, which is why I said that the Basoche's presentation of the reader is 'provocative', in that it ironically represents the production of the 'simulacre' - which 'is and will be portrayed' - as an impersonal and univocal act. The identity generated is an imagined construct that perpetuates elements of the life of the individual beyond their death ('vif en vertus').

Late-medieval French writers like de La Vigne engaged vigorously with these complex dynamics of time and being in what I have called 'epitaph fictions'. These are: narrative fictions in prose or verse which are caught up in the act of representing the dead in ways which explore interrogatively relations between death and human identity. Such texts proliferate in particular amongst the group of writers whom criticism has dubbed 'grands rhétoriqueurs': court historiographers and poets from between around 1430 and 1540 who, in relation to the current context, were charged with producing commemorative works on the occasion of a noble death. They include de La Vigne’s set of 'Epitaphes en rondeaux de la Royne' (1514), which were reportedly embroidered into the funeral drapes of Anne of Brittany, whom he served as secretary, and published in pamphlet form at the end of the ceremony, ander Jean Bouchet's Jugement poetic de l'honneur femenin (1538) in memory of Louise of Savoy, Francis I's mother. ${ }^{7}$ Where the present article parts company from previous assessment of these works is in its sense of several writers' goal in contriving an epitaph fiction. Most critics have assumed that they aimed to immortalize the deceased's reputation as an immutable product: 'le lieu d'une vitrification de l'écriture car il s'agit d’une transformation

\footnotetext{
${ }^{7}$ Jean Bouchet, Jugement poetic de l'honneur femenin, ed. by Adrian Armstrong (Paris: Champion, 2006) (henceforth $J P H F$ ).
} 
destinée à rendre le texte imperméable à l'histoire'. ${ }^{8}$ The epitaph signifies 'l'ultime stabilisation du Temps par l'écriture', ${ }^{9}$ supposed to ‘fixer pour l'éternité la vérité poétique’, ${ }^{10}$ with its textuality being ‘une pratique mémoriale, embaumante, qui fixe, qui immobilise, qui retient, qui conserve’. ${ }^{11}$ The text, especially in verse, is accorded compensatory force which serves, in Sophie Garnier's words, -to 'réparer par la facture du poème la fracture de la mort'. ${ }^{12}$ For example, in the quotations above from the Complaintes et Epitaphes du roy de la Bazoche, the homonymy between 'pierre' (stone) and 'Pierre' (the deceased individual) can be seen to promote the textually depicted tomb as a means of restoring substantial presence to the absent king.-Thilst the provision of epitaphs is portrayed as an effortful counteraction to hypostasized death's theft of Pierre, returning life to him through praise of his virtue. I propose that Garnier'ssuch a conceptualization is both too neat and somewhat reductive. Of course authors strive to honour the deceased through a textual monument to their status and posited virtue, but literary monumentalization should not be viewed monolithically. Writers such as de La Vigne, Bouchet and, in the Burgundian court, Jean Lemaire were at least as interested in using their several commemorative compositions to pose questions about the processes by which someone's posthumous identity is transmitted: the agencies involved, the interpretative acts at issue, the articulation of a life after death. They thereby expose the malleability, even the precarity, of epitaphic discourse as an act of communication to posterity, unravelling the threads of reputation in the very act of composing someone's afterlife. Thus, one could discern a significant measure of selfconsciousness in de La Vigne's memorializing verse: seeing it to probe interrogatively how the deceased is located in stone and text, and to raise as a question the agency engaged in according posthumous identity. It opens up to the future, rather than closing down, the process of identity transmission. It also interrogates the nature of that identity - the extent to which it stands as a

\footnotetext{
${ }^{8}$ Jean-Didier Urbain, L'Archipel des morts: le sentiment de la mort et les dérives de la mémoire dans les cimetières d'Occident (Paris: Payot \& Rivages, 1998), p. 207.

${ }^{9}$ Estelle Doudet, Poétique de George Chastelain (1415-75): un cristal mucié en un coffre (Paris: Champion, 2005), p. 528.

${ }^{10}$ Daniel Poirion, 'Les Tombeaux allégoriques et la poétique de l'inscription dans Le Livre du cœur d'amour épris de René d'Anjou (1457)', in Écriture poétique et composition romanesque (Orléans: Paradigme, 1994), pp. 399-414 (p. 404).

${ }^{11}$ Urbain, L'Archipel des morts, pp. 195-96.

12 Sophie Garnier, 'Rhétorique de la consolation dans la déploration funèbre des grands rhétoriqueurs', in Les funérailles à la Renaissance, ed. by Jean Balsamo (Geneva: Droz, 2002), pp. 389-402 (p. 397).
} 
continuation of the person in life (still 'vif en vertus') and/or its status as a mode of being akin to resemblance ('simulacre') which offers a figure dislocated in some way from the living, a strange similitude.

In what follows, I wish to unpack further what I mean by writers' interest in the epitaphic processes of identity construction and their precarities, focusing especially on the plurality of identity narratives that results from competing agencies shaping a person’s afterlife. I will then address their questioning of the nature of reputation as an afterlife, and explore how the mode of posthumous being that is envisaged is (or is not) defined in terms of life and death. These discussions will conclude with a reflection on how late-medieval epitaph fictions may usefully inflect critical thinking on afterlives.

\section{Pluralizing personhood: identity and narrative}

Identity is never unitary, and literary epitaphic effort to establish a desired version of someone’s life for posterity frequently recognizes this plurality. This is unproblematic in situations of complementarity: in the Complaintes et Epitaphes du roy de la Bazoche, we are invited to appreciate its eight onzain epitaphs collectively, and are cued into doing so by the Basoche of Dijon:

Soubz ce sercueil, le recueil de la plume,

Par divers vers deçà et delà plume

L’orde vilaine $[\ldots]^{13}$

Use of apposition in line 540 invites a literary reflexive reading.: Pperiphrastic description of the coffin as the 'gathering together' ${ }^{14}$ of the deceased's remains (taking 'la plume' as an honorific antonomasia for Pierre) activates a metatextual understanding of 'recueil' as a collection of writings, like the epitaphs of the Complaintes et Epitaphes du roy de la Bazoche, which, through their texts, are constituting deictically Pierre’s resting place. ${ }^{15}$ The sentence’s continuation into lines $541-42$ similarly prompts a metatextual interpretation in its antonomasiac statement of how Death ('l'orde

${ }^{13}$ CERB, 1l. 540-42.

14 'Recueil' can mean 'shelter', which also makes sense here, but I think that the poet is playing on the sense of the verb 'recueillir', and that we are triggered to appreciate this play by his paronomasia on 'plume' as both noun and verb in rhyme-position in ll. 540-41.

${ }^{15}$ Two further epitaphs are added to the end of the poem; see Swift, Representing the Dead, p. 15. 
vilaine') scours with worms Pierre's decaying body. Exploitation of homonymy between 'vers' (worms) and 'vers' (verses) was commonplace in medieval poetry about death, ${ }^{16}$ but is handled more specifically here to direct us how to set about reading the epitaphs' verses, apparently by picking elements off different lines here and there. What is in fact going on is a complex variation on an acrostic: across all the onzains, the last letters of the last word of each line or succession of lines, when put together, spell out a further commemoration of Pierre, a Latin requiem blessing: 'Requiem eternam dona dona [sic] eis domine et lux perpetua luceat eis’ ${ }^{17}$ For example, lines 463-64, quoted above, furnish the 're' of 'requiem'; lines 540-41, the 'e' of 'eis'. The epitaphs together thus perform, in miniature, a mass of the dead for the deceased, enacting what the author promotes as the proper attitude of reverence in memory of Pierre and encouraging the same amongst his audience.

However, plurality of representation also entails the risk of counter-narratives, as evoked by the persona of the Complaintes et Epitaphes du roy de la Bazoche:, who, after the Basoches have presented their verses, he sees some people ‘faire entr’eulx une contre epitaphe’ (l. 557), bringing a contrary, deprecatory rather than laudatory, representation of Pierre's character to bear. That the reality of the king's identity is linguistic is underscored by the interpretative dexterity of the persona, who undoes the validity of the proposed negative portrait by converting it formally into a positive image: he reads the decasyllabic lines of the contrary huitain 'cyrographe' (l. 556) in a different arrangement from how they initially appear. A continuous reading of the eight 4+6-syllable lines denigrates those who mourn Pierre’s death, but a reading across the lines $(4+4+$ etc., and 6+6+etc.) commends such commemoration and prayer as befitting the king. We can see how this alternative reading works in the first two lines of the huitain:

$\begin{array}{ll}\text { Mauldit soit-il } & \text { Qui pour lui priera } \\ \text { Qui en rira, } & \text { Il sera comme saige. (CERB, ll. 562-63) }\end{array}$

In a sequential interpretation, one reads: 'cursed be he who prays for him; he who mocks him will behave wisely'; but, reading cross-wise, one discerns: ‘cursed be he who mocks him; he who prays

${ }^{16}$ As in the various poems bearing the title Vers de la mort by Hélinand de Froidment, Robert Le Clerc and Adam de la Halle: see Jacqueline Cerquiglini-Toulet, 'Les Vers comme héritiers: aspects de la poétique du testament aux XIV ${ }^{\mathrm{e}}$ et XV $\mathrm{XV}^{\mathrm{e}}$ siècles’, Il Cadavere/The Corpse, Micrologus, 7 (1999), 345-57 (pp. 356-57).

${ }^{17}$ The phrase is the introit in the liturgy for the Mass of the dead. 
for him will behave wisely'. What is thus aAt stake in the jostle for how formally to read the alternative epitaph's lines is both the constitution of Pierre's posthumous identity and the conditioning of audience reception, highlighting the dependency of the deceased's afterlife both on the future reader's attitude (devotion or mockery) and on her/his textual interpretative powers.

De La Vigne’s Complaintes et Epitaphes du roy de la Bazoche is a particularly virtuosic illustration of how epitaphic discourse makes of a person’s identity a story to be shaped: the identity is itself a narrative construct and there are several possible narrative versions of that identity. Narratologically, in the terms of Paul Ricoeur,each epitaph is 'l'unité narrative d'une vie', to borrow the terms of Paul Ricoeur; - however meagre, partial or non-chronological the biographical tale that it tells, 'le récit construit l'identité du personnage, qu’on peut appeler son identité narrative'. ${ }^{18}$ The temporality of epitaphic discourse is non-linear and malleable, its emphasis often lying on the downstream context of what someone becomes after death. Jean Bouchet wrote his Temple de Bonne Renommee (1517) in memory of Charles de La Trémoille; in one of the Temple’s chambers, commemorating inventors and entrepreneurs, the protagonist finds the tombs of Lydian innovators of monetary economy:

Dessus lequelz estoit escript: 'Nous sommes

Qui achaptons et revendons aux hommes,

Ditz Lidiens, et cest art nous trouvasmes

Premierement, et nous y excerceasmes. ${ }^{19}$

Flexible tense usage portrays them looking both backwards and forwards in a 'present [that] is pregnant with both past and future'. ${ }^{20}$ The speakers describe the process by which they have become what they now are: their past actions (in life: 'trouvasmes', 'exerceasmes') have come to constitute their posthumous reputation, that is, what they are known for having done and thus stand in the present tense as emblems for doing ('achaptons', 'revendons', and so 'sommes') to those who view their grave. The distinction between past and present tenses flags up the question of perspective and, once

${ }^{18}$ Soi-même comme un autre (Paris: Seuil, 1990), pp. 193, 175.

19 Jean Bouchet, Temple de Bonne Renommee, ed. by Giovanna Bellati (Milan: Vita e Pensiero, 1992) (henceforth TBR), ll. 3865-68.

${ }^{20}$ Cave, 'Epilogue', p. 141. 
again, the determining role of audience: 'what someone is held to do/have done’ is a more powerful influence on perception than simply 'what someone did'.

\section{Posthumous reputation: a matter of life or death?}

The temporal location of the dead and the degree to which they are seen, post mortem, to be animated, plays into a much broader question of posthumous deixis explored by late-medieval writers: what is the 'here' and 'now' of existence beyond the grave? Bouchet's Lydians define their current position in implied opposition to an 'y' of earthly life. The whole premise of the Temple de Bonne Renommee is its protagonist's quest to find his deceased lord Charles, as an answer to his question: 'mais en quel lieu l'auroit on emporté?' (TBR, 1. 571). His naïvety in posing a question predicated on there being a straightforward and unitary answer is revealed via Bouchet's narrator-persona who shadows the protagonist's search. The latter's epistemological journey assists us as audience in recognizing that 'placing' the dead is not a matter simply of coming across them in a given place, but of structuring their identity and their very existence in a mode defined as different from both life and death. The spatial and the temporal necessarily interrelate in writers' delineations of the ontology of that mode of being.: Aas Mary Carruthers notes, quoting Augustine, 'in order to conceive of time, [...] we use a notion of space', ${ }^{21}$ and it in only in relation to temporal and spatial locators that we can attempt to define any voice from beyond the grave, such as the Temple de Bonne Renommee's Lydians. Yet, however hard we try, it always proves to be what Dominique Rabaté has called a 'voix narrative insituable': ${ }^{22}$ the voice as afterlife is a defamiliarization in respect of both living and being dead.

Writers tackle the articulation of an afterlife's ontology in a variety of ways, frequently engaging with terms of life and death precisely in order to problematize them through discontinuity

21 'Meditations on the "Historical Present” and "Collective Memory” in Chaucer and Sir Gawain and the Green Knight', in Time in the Medieval World, ed. by Chris Humphrey and W. M. Ormrod (York: York Medieval Press, 2001), pp. 137-55 (p. 148). It is also the case that certain medieval French deictics function both temporally and spatially, notably cy: ‘il signifie donc “ici”, pour l'espace, “maintenant” pour le temps': Claude Buridant, Grammaire nouvelle de l'ancien français (Paris: SEDES, 2000), p. 532 § 431.

${ }^{22}$ I quote from Rabaté's discussion of the fictional trope of a voice from beyond the grave: Poétiques de la voix (Paris: Corti, 1999), p. 67. 
and paradox. For example, back in the Complaintes et Epitaphes du roy de la Bazoche, de La Vigne implies a logical compensatory discontinuity: Death has taken away Pierre’s life, and so he can only live on symbolically in his reputation for virtue ('vif en virtus'); however, one should be careful in assuming a relationship of inferiority - should the life of reputation really be seen as a concessive 'only’ that cannot match up to actual temporal existence? The Temple de Bonne Renommee’s Lydians suggest not, in their promotion of the potency of reputation as life-defining; afterlife is construed as a dynamic incarnation - an animated re-presentation of someone's personhood. Bouchet tackles the definition of afterlife in terms of a death/life binary at several points in his epitaph fictions. In the Jugement poetic de l'honneur femenin, which stages an allegorical judgment of Louise of Savoy's virtue, personified Honneur explains that Louise’s just installation on a throne of honour (JPHF, 1. 3706) establishes her new being: 'Et morte elle est pour toujours icy vivre’ (1. 3673). Hyperbaton in the first hemistich of line 3673 contributes to a sense that a particular kind of existence is being described, as well as to the formation of an approximate chiasmus 'morte'/'vivre'. There is a dislocation implied in the progression from one mode to another, but no necessary paradox: it is possible to read 'morte' as either past participle ('she has died') or adjective ('she is dead'). The spatial deixis ‘icy’ has a helpfully ambiguous referent, designating the palace within which her throne is said to sit within the architectural fiction, but equally gesturing to the text in which her renown is composed. The death/life binary appears in a similar logic, and similarly succinctly, in the authorial prologue to the Temple de Bonne Renommee, in which Bouchet sets out his aim to record in his the memorable deeds of Charles and of other 'honnorables personnes long temps a trespassees et encores par bon renom vivantes' (p. 228, ll. 46-48). 'Trespasser' seemingly serves as a straightforward synonym for 'mourir'; however, in the Jugement poetic de l'honneur femenin, in a passage preceding Louise's installation, a difference in meaning is established between the two when Bouchet, through the voice of Bonne Renommee, articulates the nature of her afterlife:

Car morte n'est, mais bien est trespassée

Et de ces lieux en aultres est passée.

Où la verras (si diligence fayz)

En gros honneur et hors du mondain faix. (JPHF, ll. 305-8) 
The two verbs for 'to die' are manipulated so as to open up an implied semantic distinction between them. 'Mourir', as an ontological statement, is refuted ('she is not dead'): Louise is posited as being in some sense still alive and discoverable, her honour sustained and transmuted into posthumous renown. 'Trespasser', meanwhile, is affirmed as an account of movement, a spatial transition of her position from one place to another, passing over/beyond/away into a different deictic location defined prepositionally apart from and outside mortal existence ('de ces lieux', ‘hors $d u$ mondain faix').

Two episodes in the main body of the Temple de Bonne Renommee's fiction see Bouchet explore the nature of afterlife in a more thoroughgoing way. The first is a sermon by Bonne Renommee in which she proposes a conceptual schema adumbrating a model of three kinds of life lived by the virtuous:

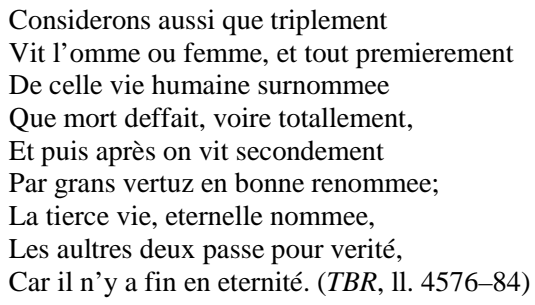

Such intensive repetition of 'vivre'/'vie' seems to put stress on the signifying capacity of the term, signalling a need for a conceptual adjustment to its normal parameters of meaning in order adequately to account for the new realities it represents. In a Petrarchan spirit of triumph over death, the first life is clearly configured as inferior to the other two modes of living, which are not conditioned or constrained by a death/life binary; the third mode, implied as the spiritual perdurance of the soul, is posited as the greatest. An unresolved point of interest is the implied temporal relationship between the second and third lives. A clear chronological progression is stated between the first and second ('et puis après'), but whilst the third is said to exceed the other two in its eternity, the second is also accorded a timeless duration when the speaker adds: 'Les bons je faiz sans fin au monde vivre' (l. 4637). These three lives as modes of being seem to correspond to three objective correlatives that frame them spatializingly: the body, an effigy, and heaven, as becomes apparentelear in the second episode to probe afterlives, the translation of Charles's remains to Thouars. 
The last five hundred lines or so of the Temple de Bonne Renommee both fulfil the protagonist's quest to locate his late lord and, through Bouchet's handling of this dénouement, reconfigure our understanding of the 'lieu' or 'manoir' that contains him. The protagonist conveniently arrives in the chamber of the Temple that Charles occupies just in time for his obsequies, which feature Bonne Renommee's oration. During the ceremony, prayers are sung over the deceased's body as intercessions for his soul; those attending offer orisons over 'le noble corps, duquel l'ame est là mont' (l. 4473): his first life having ended, his third life in eternity is attended to by his mourners. At the end, Abbess Mémoire presents a sculpture of Charles:

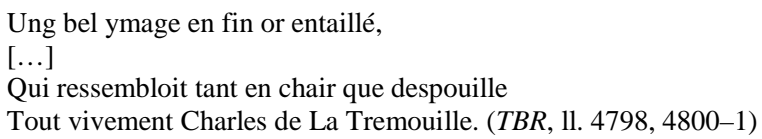

The description seems to delineate a transi tomb, a type of late-medieval double-decker funerary monument that featured, beneath the sculptured dead represented nobly in their social station as in life ('en chair'), a macabre effigy of their decomposing corpse ('despouille’). ${ }^{23}$ The sculpture’s effigial representations of Charles remind us of the 'simulacre' in the Complaintes et Epitaphes $d u$ roy de la Bazoche: it both sustains elements of the living noble (note use of 'vivement' as the adverb selected to qualify the nature and degree of resemblance) and signals a transmutation of that life into something 'other', precisely because it is posited in a relationship of similitude and not identity. The effigy thus correlates to the second life of (good) reputation, and serves as a useful point of reflection for thinking about posthumous identity being defined in terms of living/dead.

As Elizabeth A. R. Brown has discussed, an effigy represented a (noble) individual's posthumous persona, a sense of her/his identity suspended somewhere between the corpse and the office of the person. ${ }^{24}$ There is thus a sense of the effigy looking both backwards, at the life of the individual ${ }_{2}$ and forwards: towards the individual's resurrection (the presence of their effigy serving to encourage ongoing intercessory prayer after the burial of the body), as well as towards the sustained

${ }^{23}$ See Paul Binski, Medieval Death: Ritual and Representation (London: British Museum Press, 1996), pp. 139-52.

${ }^{24}$ Brown, 'Royal Bodies, Effigies, Funeral Meals, and Office in Sixteenth-Century France', Il Cadavere/The Corpse, Micrologus, 7 (1999), 437-508 (p. 486) 
honour of their reputation and that of their office. ${ }^{25}$ Views vary as to the life-like quality of these sculptures: whether the term representacion used, for instance, in the will of Louis d'Orléans in 1403, denotes an effigy actually resembling the deceased duke or object(s) closely associated with him, ${ }^{26}$ or even a theatrical representation of the dead by living actors; ${ }^{27}$ whether the use of effigies attests to medieval belief in the sustained vitality of the corpse, drawing on evidence such as the earlysixteenth-century custom in royal funeral services of serving a post-mortem meal to the corpse; ${ }^{28}$ how the effigial representation relates to the body of the deceased, ${ }^{29}$ for example the existence of effigies showing a person in the very moment of their death, including signs of the injuries from which they died. ${ }^{30}$ Whatever one's view, it is clear that, at least in terms of modern critical readings of latemedieval effigies, these sculptural simulacra fascinate for the questions to which they give rise regarding an audience’s perception of the person whose identity they mark.

In response to the appearance of Charles's effigy in the Temple de Bonne Renommee, personified chivalric qualities superintending each of the Temple’s chambers (Religion, Discipline Militaire, Prudence, etc.) all lay claim to him as a suitable occupant. Bonne Renommee acts as arbiter of their competing claims and accords him instead to Prouesse, whose chamber is designated by the persona as 'lieu nouveau que je n'avois onc veu' (TBR, l. 4848). Besides serving the function of further elevating Charles’s honour by associating him with yet another crowning virtue, the persona's formulation signals how a reorientation of perspective on what constitutes 'place' is necessary. The location of Charles suddenly pluralizes, as we are told that his body is transported to his birthplace, Thouars, for its burial:

\author{
Au propre lieu de sa nativité, \\ C'est à Thouars, fut par ceste cohorte \\ Transporté lors en lachrymose sorte. (TBR, 1l. 4867-69)
}

\footnotetext{
${ }^{25}$ Brown, 'Royal Bodies', pp. 446-49.

${ }^{26}$ Brown, 'Royal Bodies', p. 446, n. 2; cf. Michael Camille, Master of Death: The Lifeless Art of Pierre Remiet, Illuminator (New Haven/London: Yale University Press, 1996), p. 186.

${ }^{27}$ Colette Beaune, 'Mourir noblement à la fin du moyen âge', in Colloque de la société des historiens médiévistes de l'enseignement supérieur public: la mort au moyen âge (Strasbourg: Istra, 1977), pp. 125-43 (p. 129).

${ }^{28}$ Brown, 'Royal Bodies', pp. 451-57.

${ }^{29}$ Binski, Medieval Death, pp. 93-94, 149.

${ }^{30}$ Philippe Ariès, L'Homme devant la mort (Paris: Seuil, 1977), pp. 116-18.
} 
At this point, tablets are produced engraved with huitain epitaphs 'pour actacher dessus sa sepulture' (l. 4879). These are composed by eleven personified chivalric qualities that are intended to accompany the body to its new resting place; for example: 'Cy gist le cueur d'un prince tresnotable' (l. 4898: Foy Publicque); 'Cy gist en cendre ung corps dessoubz la lame’ (l. 4938: Prudence). We encounter thereby another interaction of 'vers' and 'vers', as in the Complaintes et Epitaphes du roy de la Bazoche: the epitaphic verses are composed out of the decomposition of the corpse, restoring poetically a kind of vitality to Charles through their commemoration. We are reminded of Garnier’s conception of the role of commemorative poetry being to 'réparer par la facture du poème la fracture de la mort' (cited above, pp. 15-16), which seems particularly pertinent given that, earlier in the Temple de Bonne Renommee, Charles was portrayed as 'luy qui est brizé, cassé' (1. 505). However, what we see happening in these texts is less a restoration of a lost whole and more a transformation into a new form: a new textual body. By the end of the Temple de Bonne Renommee, it appears that the protagonist has realized his objective of locating Charles - indeed, emphatically so insofar as the spatial deixis of the virtues' epitaphs ('cy gist') is only fully realized when they are positioned on the tomb, in the family vault in the Church of Our Lady in Thouars, to which he is also transported. In one sense, he has found his lord in respect of body, name, and soul: he attends his burial, he witnesses his commemorative effigy being installed in the Temple, and he is able to join in intercessory prayer for his salvation. But in another light, and surely a key irony of this search, he does not find Charles, at least not in any fixed or restrictive sense. The point of Charles's renown is not to be contained but to be disseminated, hence the protagonist's request of the narrator-persona to write down the epitaphs ('ce que dict est', l. 5067) and publish them in honour of his master's valour, eternal memory and in service of the glory of his soul. All three of his lives, in other words, are to be conveyed through textual work.

A sense of afterlife as transformation rather than restoration, privileging a downstream context rather than harking back to an anterior state, is also promoted in the final work I wish to consider, Jean Lemaire de Belges's prosimetrum Le Temple d'Honneur et de Vertu (1503), written in memory of his former employer, Pierre II de Bourbon, and dedicated to his widow, Anne de Beaujeu.

The work's fictional narrative unfolds in two phases; in the second, deceased Pierre is enthroned in 
the eponymous Temple - a now-familiar spatializing, dream-narrative template. The persona stands in the position of dreamer-observer; his and our interpretative guide in the text is Entendement, who presents the enthroning scene as a consolatory vision directed at Anne in order to transmute her grief, Artemis-like, into honour of her late husband's illustrious reputation. In some respects, thereforen, Pierre's installation is quite conventional, ${ }^{31}$ but there are certain remarkable features which suggest Lemaire's interest in probing interrogatively the nature of afterlife as reputation. The first is Entendement's moment of self-correction when speaking of Pierre’s death: 'Le trespas, que diz je! trespas, non! non! j'ai failly, mais la transmigration de ton seigneur en meilleur lieu'. ${ }^{32}$ Given the directness of Entendement's didactic discourse elsewhere, this is not simply a case of tactful rephrasing; rather, I see the reformulation as a prompt for reflection on what is signified by 'trespas': its functional synonymy with 'death' is shunned in favour of drawing out its etymological meaning of locational transposition, which is emphasized in the quadrisyllabic spatializing synonym ‘transmigration’ and the additional prepositional phrase ‘en meilleur lieu’; the movement is thus cast as a wholly positive elevation into a superior phase of existence.

The sort of 'lieu' that Entendement intends is two-fold. On the one hand, it denotes a secure installation in the resting-place of the Temple, which, in this text, carries a sacramental valence as the home of ‘benoistes ames’ (THV, l. 921): ‘il a passé le commun mortel pas des vivans pour venir vivre immortellement en ce beau manoir, en ce souverain habitacle, et en ce divin temple’ (ll. 911-12); in the terms of Bonne Renommee in the Temple de Bonne Renommee, this would be 'la tierce vie'. On the other hand, it is not a fixed abode that Entendement designates, but a downstream path of transmission, corresponding to Bonne Renommee’s second life: those who are worthy of honour, he states, 'par la memoire de leurs gestes vertueux, revivent et reflourissent de jour en jour et volent en la bouche des meilleurs' (ll. 856-58). Reputation is presented as communication, process rather than product - and specifically a dynamic process of renewal and revival. One of these 'bouches', within the fiction, is Entendement; at the end of Le Temple d'Honneur et de Vertu, he is depicted flying off

${ }^{31}$ On the didacticism of late-medieval architectural fictions, see David Cowling, Building the Text: Architecture as Metaphor in Late Medieval and Early Modern France (Oxford: Clarendon Press, 1998).

32 Jean Lemaire de Belges, Le Temple d'Honneur et de Vertu, ed. by Henri Hornik (Geneva: Droz, 1957), 11. 845-47. 
to disseminate ('publier et preconiser', ll. 1217-18) Pierre de Bourbon's reputation. His act of oral transmission at the work's close finds pertinent parallel at its approximate mid-point, where, introduced as an 'invisible voix' (1. 650), Entendement first appeared in the text voicing a rondeau acclaiming Pierre:

Au bruyt! Au bruyt de la louenge excelse Du duc illustre, accourez tous et toutes! (THV, ll. 651-52)

His invocation is presented as an oral utterance calling upon other voices to lend the sonic force of their 'bouches' to praise him ('bruyt' carrying the sense of both 'reputation' and 'sound'). There is also a kind of symmetry with the opening of the first part of Le Temple d'Honneur et de Vertu, a pastoral fiction of the god Pan (who, Entendement later discloses, poetically represents Pierre) falling ill and dying; prefacing this mythological narrative are the songs of shepherds and shepherdesses, such as Amyntas and Galatea, in combinations of verse forms. Such '[...] chant bucolicque / Sans noyse oblicque' (ll. 115-16) seems to privilege oral communication over written record, mobility over fixity, an impression reinforced by the shepherds' return to the narrative at the end of the second part. When Entendement flies off, we see the rustics engraving sixain epitaphs into the wall of the Temple; contributing to the work's didactic purport for its extratextual audience, the epitaphs draw attention to themselves through the unexpected phrasing of their incipit in respect of Pierre:

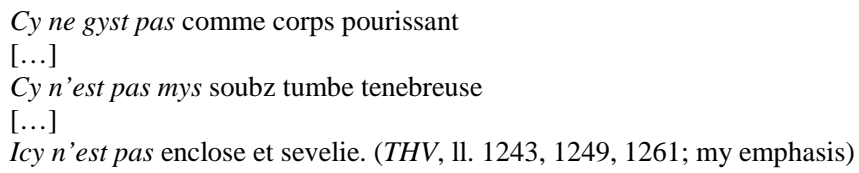

They seem at first to stand as anti-epitaphs, denying that Pierre can be found there; however, what their negation merely makes explicit something that is in fact already implicit in the habitual formula 'cy gist': namely that-what lies beneath, in terms of decaying physical remains, does not constitute the most significant posthumous identity of the deceased, her/his afterlife, which is instead dispersed through transmitted reputation. Its lack of solid anchor fixing it to a secure point, thereby affirming it as absence rather than presence, discloses its precarity; but, at the same time, its status as ‘insituable’, to pick up on Rabaté's term, is its source of potency, its capacity, through dissemination via a network of voices, to 'reviv[re] et reflouri[r]'. 
Afterlife after death

Echoes of recent critical discussion of afterlives will have been discernible at times in the above analyses; the ways in which epitaph fictions cue reflection on identity intersect fruitfully with various aspects of that discussion, as well as offering interesting inflections of it. Afterlives have been troped as 'returns from the dead'; ${ }^{33}$ in epitaph fictions, we are concerned literally with post-mortem existence, though, as we have seen, the nature of posthumous identity is not straightforwardly definable in terms of life and death, and the deceased's afterlife is not necessarily in opposition to either earthly living or her/his demise. Afterlife itself has been promoted as an approach to represented identity that 'seek[s] to resist the teleological drive', ${ }^{34}$ and epitaphs function similarly: telling the story that is someone's life from a posthumous perspective, thanatographically, and casting the story of their life as encompassing both death and a post mortem phase of existence upset any simple chronological link between life and death, 're-calibrat[ing] the relation between 'after-' and 'life'. ${ }^{35}$ Viewing life from the point of view of death does not always lead writers to fix life commemoratively, to strive to preserve it as a known, valued experience.; Iit can prompt instead a defamiliarization - a loosening up of our perspective on what life is, dislocating it from a death/life binary as well re-assessing its status: life is not innately superior to death; indeed, identity in death is valued more highly. That an afterlife does not represent an etiolation of a prior original, a diminished residue of an originary source, ${ }^{36}$ is entirely consonant with the mentality of the period: a medieval understanding of death is as 'a transition, a change in status, not an end' ${ }^{37}$ It signals passage (hence the contemporary periphrasis for death: 'passer le pas') into another phase and mode of being; death is still part of the story of someone's life. In a Christian world-view, ${ }^{38}$ life itself is a journey from and

\footnotetext{
${ }^{33}$ Noted by Holland and Scholar, p. 8.

${ }^{34}$ Holland and Scholar, p. 8.

${ }^{35}$ Holland and Scholar, p. 5.

${ }^{36}$ Cave, Mignon, p. 36.

${ }^{37}$ Andrea Petö and Klaartje Schrijvers, eds., Faces of Death: Visualising History (Pisa: Pisa University Press, 2009), p. xviii.

${ }^{38}$ What Claude Blum calls the 'récit invariant chrétien': La Représentation de la mort dans la littérature française de la Renaissance, 2 vols, 2nd edn. (Paris: Champion, 1989), I, p. 10.
} 
(back) towards God; in this light, death is also not a negative notion. We see this most clearly, within this article's corpus, in Le Temple d'Honneur et de Vertu's underscoring of 'trespas' as ‘transmigration en meilleur lieu’.

Death as ‘transmigration’ brings into play the relationship between afterlife and translation: ‘The literal sense of 'translation’ acts [...] as a guiding and constraining point of reference: the relationship between the originating text and its afterlives must always be tangible' ${ }^{39}$ Translation is evidenced in our epitaph fictions in common and in more particular ways $\div$ Lfor example, linguistically, for example, in how-letters from the vernacular onzains of the Basoches in the Complaintes et Epitaphes du roy de la Bazoche transform into a Latin prayer.; Fformally, we find interaction between prose and verse both in and between prosimetra: the second part of Le Temple d'Honneur et de Vertu is a re-modelling of Le Trosne d'honneur, an epitaphic work in memory of Philip the Good composed by Jean Molinet, Lemaire’s predecessor as Burgundian indiciaire whom he also references in the full title of his prosimetrum, casting himself as 'disciple de Molinet' (p. 41). There is also a cultural translation in the transposition within Le Temple d'Honneur et de Vertu between mythological narrative in its first part and the allegorical fiction of the Temple in its second. Most peculiarly pertinent to a medieval context, we find the very concrete, literal sense of translatio as applied to the translation of relics - privileged body parts - from one location to another. ${ }^{40}$ Whilst none of the examples discussed above touches on the death of saint, ${ }^{41}$ physical translation is present in the recounted transfer of Charles de La Trémoille's body to Thouars following his funeral ceremony elsewhere and the consignment of his effigy to a chamber in the Temple de Bonne Renommee. The plurality of the Temple de Bonne Renommee's spatial deixis - its several evocations of the 'here' of commemorative activity, together with the several dimensions of existence (body, name, soul) to which Bonne Renommee’s three lives correspond - reminds us that personhood, in a

\footnotetext{
${ }^{39}$ Cave, Mignon, p. 40.

${ }^{40}$ See, for example, Theo Hermans, 'What is (Not) Translation?', in The Routledge Handbook of Translation Studies, ed. by Carmen Millán and Francesca Bartrina (London: Routledge 2013), pp. 75-87.

${ }^{41}$ Epitaphs for female saints, with especial attention to martyrs, appear in the palace of Honneur Femenin in JPHF.
} 
medieval understanding, was not unitary. One notes, for example, the practice of multiple burial: of dividing the body to allow parts to be interred in different, especially valued places. ${ }^{42}$

The personhood of afterlife in late-medieval epitaph fictions is also not unitary in a further sense: someone's posthumous identity does not sit in a stable or easily definable relationship with their self (or, indeed, selves) in life. As Holland and Scholar affirm, the notion of afterlife fosters an 'open attitude [...] towards identity and resemblance in both defining and tracking the cultural object'. ${ }^{43}$ That object for us is the deceased's identity, and we have seen how the figure of the effigy may be understood to capture some of the slipperiness of its strange similitude. The precarity of reputation as a malleable entity, a tussle between different versions constitutive of good or ill repute, is also part of that openness, making of posthumous identity a process rather than a product: an interpretative juggling act between clusters of 'hermeneutic coordinates', ${ }^{44}$ like the versificatory puzzles in the Complaintes et Epitaphes du roy de la Bazoche offering different ways of construing the ‘contre-epitaphe’ for Pierre de Brezé. Each record of a life through epitaphic discourse is itself an afterlife, a 'life made anew' ${ }^{45}$ 'Cy gist' may thus be viewed less as a statement of a state of being than as a trigger for an act of doing, a question rather than an affirmation. Posthumous identity does not lie waiting to be found; it requires composition and is predicated on a location in the here and now of the future reader whose piecing together of that identity will itself be an act of invention. By all passers-by ‘est et sera pourtraict le simulacre’ after life and death.

\section{Biography}

Helen Swift is Associate Professor of Medieval French and Tutorial Fellow of St Hilda's College at the University of Oxford. Having focused for several years on the fifteenth-century querelle des femmes (including Gender, Writing and Performance: Men Defending Women in Late Medieval France, OUP, 2008), she now explores more broadly, as well as collaboratively, questions of

${ }^{42}$ See Brown, 'Death and the Human Body in the Later Middle Ages: The Legislation of Boniface VIII on the Division of the Corpse', in The Monarchy of Capetian France and Royal Ceremonial (Aldershot: Variorum, 1991), pp. 221-70 (p. 228).

${ }^{43}$ Holland and Scholar, p. 6.

${ }^{44}$ Cave, Mignon, p. 38. Cave identifies 'Mignon' as 'the plural set of her afterlives, the cluster of coordinates that defines her' (p. 41).

${ }^{45}$ Holland and Scholar, p. 5. 
narrative voice from Guillaume de Machaut to Jean Bouchet. Her second monograph examines

challenges to the construction of identity in the context of voices and bodies speaking from beyond the grave: Representing the Dead: Epitaph Fictions in Late-Medieval France, D. S. Brewer, 2016. 


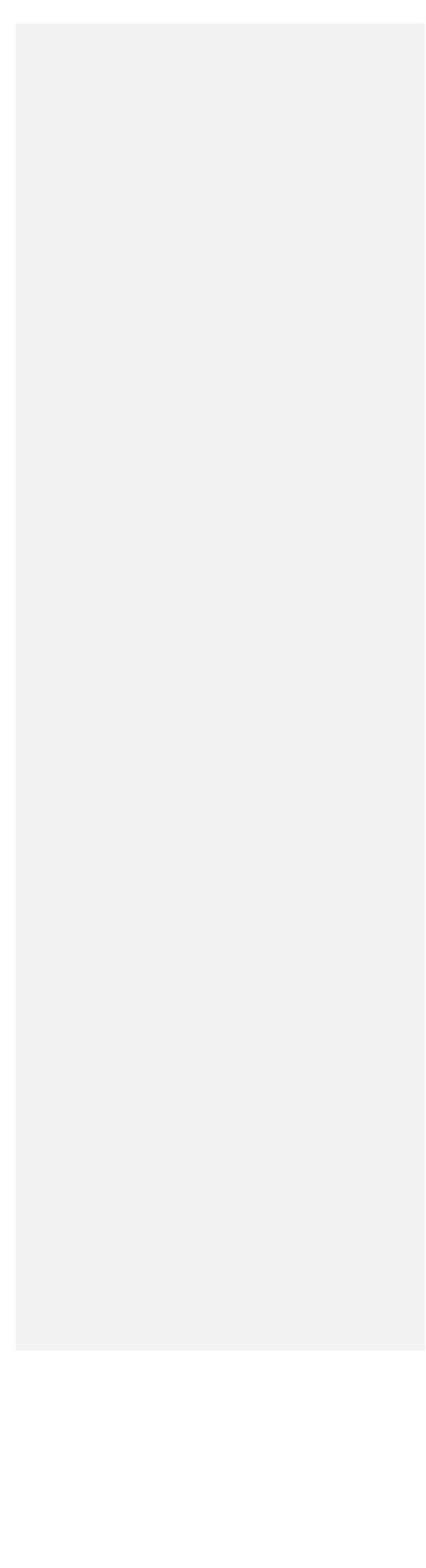

